\title{
Matrix metalloproteinases genes polymorphism in the development of new cardiovascular events
}

\section{${ }^{1}$ No1 Department of Internal Diseases, Karaganda Medical University, Karaganda city, Republic of Kazakhstan \\ ${ }^{2}$ Laboratory of Genomic and Personalized Medicine, National Laboratory Astana, Nazarbayev University, Nur-Sultan city, Republic of Kazakhstan}

Dana Taizhanova $^{1}$, Akerke Kalimbetova ${ }^{1}$, Ainur Akilzhanova ${ }^{2}$

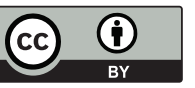

This work is licensed under a

Creative Commons Attribution 4.0

International License

Received: 2020-05-15

Accepted: 2020-07-13

UDC: 616.1

\section{J Clin Med Kaz 2020; 4(58):19-22}

Corresponding author: Akerke Kalimbetova, Master of Medicine, PhD doctoral student, Karaganda Medical University, Karaganda, 40 Gogol Street, Republic of Kazakhstan. Tel.: +77089261714

E-mail: akerke.kalimbetova@gmail.com

\section{ABSTRACT}

OThe review article presents a study of the literature on the relationship of gene polymorphism of matrix metalloproteinases (MMP $2(-1575 \mathrm{G}>\mathrm{A})$, MMP3 (-1171 5A/6A), MMP $9(-1562 \mathrm{C} / \mathrm{T})$ with the risk of developing new cardiovascular events after percutaneous coronary intervention. To achieve this goal, a systematic search and subsequent analysis of publications and online resources was carried out. All publications are indexed in Scopus, Web of Knowledge and e-library.

Key words: coronary heart disease, percutaneous coronary intervention, (MMP 2 (-1575 G>A), MMP3 (-1171 5A/6A), MMP 9 (-1562 C/T), new cardiovascular events, stenting

\section{ЖАНА КАРДИОВАСКУЛЯРЛЫҚ ОҚИҒАЛАРДЫН ДАМУ ҚАУПІНДЕ МАТРИКСТІК МЕТАЛЛОПРОТЕИНАЗАЛАР} ГЕНІНІН ПОЛИМОРФИЗМІ

\section{Д.Ж. Тайжанова ${ }^{1}$, А.Б. Калимбетова ${ }^{1}$, А.Р. Акильжанова ${ }^{2}$}

${ }^{1}$ Ішкі аурулар бөлімшесі, Қарағанды медициналық университеті, Қарағанды қаласы, Қазақстан Республикасы

${ }^{2}$ Геномдық және дербес медицина зертханасы, National Laboratory Astana, Назарбаев университеті, Қазақстан Республикасы

\section{ТҰЖЫРЫМДАМА}

Шолу мақаласында матрикстік металлопротеиназалардың гендік полиморфизмінің (MMP 2 (-1575 G>A), MMP3 (-1171 5A/6A), MMP 9 (-1562 C/T) теріішлік тәждік араласудан кейінгі жаңа жүрек-қан тамырлары оқиғаларының пайда болу қаупімен байланысы туралы әдебиеттер ұсынылған. Осы мақсатқа жету үшін жарияланымдар мен интернет-ресурстарды жүйелі іздеу және кейінгі талдау жүргізілді. Барлық басылымдар Scopus, Web of Knowledge және e-library индекстеледі.

Негізгі сөздер: жүректің ишемиялық ауруы, теріішілік тәждік араласу, (MMP 2 (-1575 G>A), MMP3 (-1171 5A/6A), MMP 9 (-1562 C/T)), жаңа жүрек-қан тамырларының оқиғалары, стенттеу

\section{ПОЛИМОРФИЗМ ГЕНОВ МАТРИКСНЫХ МЕТАЛЛОПРОТЕИНАЗ В РИСКЕ РАЗВИТИЯ НОВЫХ СЕРДЕЧНО-} СОСУДИСТЫХ СОБЫТИЙ

Д.Ж. Тайжанова ${ }^{1}$, А.Б. Калимбетова ${ }^{1}$, А.Р. Акильжанова²

'Кафедра внутренних болезней №1, Медицинский университет Караганды, город Караганда, Республика Казахстан

${ }^{2}$ Лаборатория геномной и персонализированной медицины, National Laboratory Astana, Назарбаев университет, Республика Казахстан

\section{PEЗЮME}

В настоящей статье представлен обзор литературы о взаимосвязи полиморфизма генов матриксных металлопротеиназ (ММР 2 (-1575 G>A), MMP3 (-1171 5A/6A), MMP 9 (-1562 C/T) в риске развития новых сердечно-сосудистых событий после чрескожного коронарного вмешательства. Для достижения этой цели был проведен систематический поиск и последующий анализ публикаций и онлайн-ресурсов. Все публикации индексируются в Scopus, Web of Knowledge и e-library.

Ключевые слова: ишемическая болезнь сердца, чрескожное коронарное вмешательство, (MMP 2 (-1575 G>A), MMP3 (-1171 5A/6A), MMP 9 (-1562 C/T), новые сердечно-сосудистые события, стентирование 


\section{Introduction}

Despite the progress and widespread use of percutaneous coronary intervention, the development of new cardiovascular events are decisive factors that limit its long-term effectiveness.

Today, there are a number of diagnostic concepts aimed at studying the factors affecting the development of new cardiovascular events after percutaneous coronary intervention. The structure of the developed cardiac complication depends on the nature of the intracoronary intervention procedure, the age of the patient, the presence of concomitant diseases, the degree and extent of the lesion, the length of the lesion, the diameter of the vessel lumen after implantation, and other factors.

One recent area of interest is the study of the role of gene polymorphism of matrix metalloproteinases (MMPs) in the development of new cardiovascular events.

Matrix metalloproteinases are classified according to their substrate specificity and structural similarity and are mainly divided into five classes: collagenases (MMP-1, -8 and -13), gelatinases (MMP-2 and -9), stromelysins (MMP-3, -10 and -11), metalloelastases, membrane-type MMP (MT-MMP, MMP-14, $-15,-16,-17,-24$ and -25) and others (MMP-7, -11, -12, -19, -20 and -23) [1]. In the MMP genes, polymorphic regions, nucleotide variants that are associated with the level of expression of these genes were found [1-3].

Coronary heart disease (CHD) is a polygenic disease, and hundreds of genes contribute to its predisposition. A large number of sequence variations have been identified in the MMP genes. MMP function can be modeled by certain pharmacological agents that can be used to diagnose and treat new cardiovascular events.

In a number of studies [2,3], associations of CHD with polymorphic variants of the genes MMP $2(-1575 \mathrm{G}>\mathrm{A}), \mathrm{MMP} 3$ $(-11715 \mathrm{~A} / 6 \mathrm{~A})$, and MMP 9 (-1562 C/T) were revealed (Table 1).

\section{Table 1}

\begin{tabular}{|ll|l|}
\hline Gene & & MMP 3 \\
\hline SNP & rs3025058, 5A / 6A \\
\hline Geno & Mag $\quad$ Summary & \\
\cline { 2 - 3 }$(-;-)$ & 5A/5A; higher MI risk? \\
$(-; \mathrm{T})$ & 5A/6A & \\
\cline { 2 - 3 }$(\mathrm{T} ; \mathrm{T})$ & 6A/6A; higher CAD risk \\
\cline { 2 - 3 } & & \\
\hline
\end{tabular}

\begin{tabular}{|c|c|c|c|}
\hline Gene & & & MMP 3 \\
\hline SNP & & & rs3918242, C1562T \\
\hline Geno & Mag & \multicolumn{2}{|l|}{ Summary } \\
\hline$(\mathrm{C} ; \mathrm{C})$ & & \multicolumn{2}{|l|}{ normal risk } \\
\hline$(\mathrm{C} ; \mathrm{T})$ & & \multicolumn{2}{|c|}{$1.14 \mathrm{x}$ increased risk for MI; also check haplotype } \\
\hline$(\mathrm{T} ; \mathrm{T})$ & & \multicolumn{2}{|c|}{ 1.33x increased risk for MI; also check haplotype } \\
\hline
\end{tabular}

Considering that single nucleotide polymorphisms (SNPs), initially determining the genetic background of patients, it is possible to predispose to the development of cardiovascular events through changes in MMP activity. SNP analysis allows in the early period to personify an assessment of the cause-effect relationships of the development of the disease and to predict the risk of developing cardiovascular complication [4].

According to experts [5], excessive arterial stiffness, determined by the pulse wave propagation velocity (PWV), belongs to the category of subclinical lesions of target organs associated with an increase in the incidence of cardiovascular catastrophes.
It is noteworthy that the requirements for markers of vascular elasticity are increasing. So, the vascular stiffness indicator instead of the previous recommendations with a PWV value of $\geq 12 \mathrm{~m} / \mathrm{s}$ decreased to a PWR of $>10 \mathrm{~m} / \mathrm{s}$. Based on the knowledge of arterial stiffness indicators, it is possible to predict with a high degree of probability an unfavorable scenario for the development and course of arterial hypertension ( $\mathrm{AH}$ ) in young and middle-aged people. It should be noted that the pathogenesis of the occurrence of excessive arterial stiffness can be associated with the dysfunction of matrix metalloproteinases (MMP), zinc-containing enzymes that have proteolytic activity against connective tissue proteins and are able to play one of the leading roles in vascular remodeling. Control over the activities of MMP is multi-level in which the genetic level occupies an important place.

There is evidence that one of the causes of excessive arterial stiffness in hypertension and coronary heart disease is the destruction of the intercellular matrix, as a result of the effect of cytosine replacement on the thymine of the MMP 9 (-1564) C/T polymorphism. The presence of the $\mathrm{T}$ allele is directly related to the high values of PWV [6]. A number of studies in recent years have shown striking gender differences in the presence of the $\mathrm{T}$ allele and high PWV. It was found that Chinese women with the T-allele are significantly higher than PWV, and, especially often, this relationship was observed in the group of patients during the menopause [6-7]. Moreover, not only TT homozygotes, but also CT heterozygotes have a higher PWV than $\mathrm{CC}$ homozygotes. As a result of this study, a dose-dependent effect of this mutation was suggested [8-10]. Other researchers [11] found that in individuals with signs of a metabolic syndrome, this polymorphism is functionally more active $(\mathrm{OR}=3.7)$ and is associated with the development of acute coronary events. The role of MMP2 (-1306 C/T) in left ventricular hypertrophy in hypertension has been confirmed [12], but the effect on PWV has not been studied.

In the modern period, studies on polymorphisms of MMP genes are open and are of interest, which is revealed by the existing various research designs to find the relationship of MMP with the risk of developing cardiovascular diseases.

In vivo studies have shown that genetic polymorphism has an effect on the differential expression of MMP [13]. Moreover, MMP gene polymorphisms are associated with atherosclerosis and the development of acute myocardial infarction.

One of the significant research designs is case-control. There are a number of case-control studies that have identified the potential link between matrix polymorphism of matrix metalloproteinases and cardiovascular events. Although the available results are still inconsistent, the main meta-analyzes [14-16] indicate that polymorphisms of the MMP-3 Glu45Lys and MMP9 $1562 \mathrm{C} / \mathrm{T}$ genes were associated with the risk of coronary artery disease.

Data on the relationship between the development of vascular aneurysms and the polymorphism of MMP genes are of scientific interest. Thus, a number of genetic and morphological studies indicate that the development of aneurysm with a bicuspid valve is a consequence of the disturbed structure and expression of a number of genes of the aortic wall itself: a decrease in the amount of fibrillin, fragmentation of elastin, a change in the activity of matrix metalloproteinases (MMP), especially an increase in the activity of MMP 2 and enzyme TIMP1 (tissue inhibitor of collagenase), and a decrease in the activity of MMP $1[17,18,19]$. There are indications that such changes can be caused by gene mutations; therefore, it is of interest to study the polymorphism of genes encoding these proteins and their activity regulators [20]. Interestingly, the TIMP1 gene encoding an inhibitor of MMP1 activity is located on the X chromosome [21], and its genetic variability may partly explain the observed predominance among males compared with females (3:1). 
According to other studies [22.23], in patients with a more active genotype (5A5A or 5A6A), MMP-3 also shows a predominance of MMP-3 expression in serum and tissues. At the same time, atherosclerotic plaques with a small amount of connective tissue and a thin fibrous cap, which is more often prone to rupture, which also determines clinical instability, are found in this category of patients. The results of other studies confirm that the MMP-3 5A5A genotype is important for the development of AMI [24-26], especially in the Asian population. However, the value of the $5 \mathrm{~A}$ allele in the prevalence of AMI in the European population is quite contradictory [27-29]. These studies were conducted by Germans and Italians, who did not reveal any connection between the 5M/3A MMP-3 polymorphism and coronary heart disease.

Blankenberg et al. (2003) showed that the concentration of MMP 9 was higher in patients with coronary artery disease, which would recommend it as a new predictor of cardiovascular disease. The level of activity of MMP enzymes is influenced by many factors, such as genetic MMP polymorphism, drugs, and other components [30].

Lacchini et al. (2010) found that there are interethnic differences in the genetic polymorphisms of MMPs. Thus, the distribution of the $\mathrm{T}$ allele is much higher in patients with coronary heart disease in East Asia than in residents of the West of Asia. The relationship between the MMP genotype and the concentration of MMPs also differ in different ethnic groups. In addition, there is no close relationship between the genetic polymorphism of MMP 9 and the activity of the enzyme MMP 9 in a healthy population of Europeans [31]. Although in another study (Metzger et al., 2012), a positive relationship was confirmed in African Americans [32].

In a review study by Juan et al. (2015) showed that the presence of the C-1562T T-allele of the MMP-9 gene polymorphism can be susceptible to patients with myocardial infarction only in Europeans than in Asians [33]. In contrast, in another review by Wang et al. (2014) MMP-9 C-1562T was significantly associated with an increased risk of developing myocardial infarction in the Asian population, but was not confirmed in Europeans [34].

The results of the studies can differ for a number of reasons, including demographic and ethnic differences, problems in the design and implementation of the study in terms of inclusion and exclusion criteria, the size of the sample that affects the power of the study and the analysis taking into account mixed factors.

\section{Conclusion}

Thus, the existing scientific discussions on the importance of polymorphism of matrix metalloproteinases genes in the development of heart disease, a series of confirmation of the risk of developing cardiovascular complications after interventions, the data on correlations of gene polymorphisms depending on ethnicity undoubtedly arouse interest in further scientific research on assessment of the characteristics of genetic predictors for personification and prediction of the risk of cardiovascular events.

Disclosures: There is no conflict of interest for all authors.

\section{References}

1. T. Klein, R. Bischoff. Physiology and pathophysiology of matrix metalloproteinases. Amino Acids. 2011; 41:271-290. https:// doi.org/10.1007/s00726-010-0689-x

2. Alp E., Menevse S., Tulmac M. et al. The role of matrix metalloproteinase-2 promoter polymorphisms in coronary artery disease and myocardial infarction. Genet Test Mol Biomarkers. 2011; 15(4):193-202. https://doi.org/10.1089/gtmb.2010.0113

3. Kaplan RC, Smith NL, Zucker S, et al. Matrix metalloproteinase-3 (MMP3) and MMP9 genes and risk of myocardial infarction, ischemic stroke, and hemorrhagic stroke. Atherosclerosis. 2008; 201:130-137. https://doi.org/10.1016/j. atherosclerosis.2008.01.003

4. S. Abilleira, S. Bevan, H.S. Markus The role of genetic variants of matrix metalloproteinases in coronary and carotid atherosclerosis. J. Med. Genet. 2006ж 43:897-901. https://doi.org/10.1136/jmg.2006.040808

5. Mancia G, Fagard R, Narkiewicz K, et al. The 2013 ESH/ESC Guidelines for the Management of Arterial Hypertension. European heart journal. 2013; 2159-219. https://doi.org/10.1093/eurheartj/eht151

6. Zhou S, Feely J, Spiers J, et al. Matrix metalloproteinase-9 polymorphism contributes to blood pressure and arterial stiffness in essential hypertension. J Hum Hypertens. 2007; $21: 861-7$. https://doi.org/10.1038/sj.jhh.1002244

7. Panchenko EA, Nevzorova VA, Belov PS, et al. Polymorphism of matrix metalloproteinases 2 and 9 genes in patients with myocardial infarction combined with metabolic syndrome. Fundamental research. 2014; 10:1964-70.

8. Li J, Lu H, Tao F, et al. Meta-analysis of MMP9-562C/T and the risk of coronary heart disease. Cardiology. 2013; 124(1):53-9. https://doi.org/10.1159/000345772

9. Lin RT, Chen CH, Tsai PC, et al. Sex-specific effect of matrix Metalloproteinase-9 functional promoter polymorphism on carotid artery stiffness. J Atherosclerosis. 2012; 416-20. https://doi.org/10.1016/j.atherosclerosis.2012.05.031

10. Huang R, Deng L, Shen AN, et al. Associations of MMP1, 3, 9 and TIMP3 Genes Polymorphism with Isolated Systolic Hypertension in Chinese Han Population. International J Med Scie. 2013; 10(7): 840-7. https://doi.org/10.7150/ijms.5728

11. Yadav SS, Mandal RK, Singh MK, et al. High serum level of matrix metalloproteinase 9 and promoter polymorphism - 1562 C:T as a new risk factor for metabolic syndrome. DNA Cell Biol. 2014; 33(11): 816-22. https://doi.org/10.1089/dna.2014.2511

12. Lacchini R, Jacob-Ferreira AL, Luizon MR, et al. Common matrix metalloproteinase 2 gene haplotypes may modulate left ventricular remodelling in hypertensive patients. J Human Hypertension. 2012; 26: 171-7. https://doi.org/10.1038/jhh.2011.8

13. da Fonseca, A.L.M., Oliveira, R.J.B., Santos, J.C.A., Cardoso, L.S., Couto, F.D. et all. Matrix metalloproteinases 2 and 9 are CAD more relevant biomarkers than-1,-8, and-12 to separate CAD from non-CAD patients. Open Biomarkers Journal. 2019; 9(1):22-30. https://doi.org/10.2174/1875318301909010022

14. Koch W, de Waha A, Hoppmann $\mathrm{P}$, et al. Haplotypes and 5A/6A polymorphism of the matrix metalloproteinase-3 gene in coronary disease: case-control study and a meta analysis. Atherosclerosis. 2010; 208:171-176. https://doi.org/10.1016/j. atherosclerosis.2009.08.021 
15. Zhang F.X., Sun D.P., Guan N. et al. Association between $-1562 \mathrm{C}>\mathrm{T}$ polymorphism in the promoter region of matrix metalloproteinase-9 and coronary artery disease: a meta-analysis. Genet Test Mol Biomarkers. 2014; 18(2):98-105. https://doi. org/10.1089/gtmb.2013.0369

16. Opstad TB, Pettersen A $\AA$, Arnesen H, et al. The co-existence of the IL-18 +183 A/G and MMP-9 -1562C/T polymorphisms is associated with clinical events in coronary artery disease patients. PLoS ONE. 2013; 8: e74498. https://doi.org/10.1371/journal. pone. 0074498

17. Padang R, Bannon P, Jeremy R, et al. The genetic and molecular basis of bicuspid aortic valve associated thoracic aortopathy: a link to phenotype heterogenecity. Ann Cardiothorac Surg. 2013; 2(1):83-91.

18. Fedak P, de Sa M, Verma S, et al. Vascular matrix remodeling in patients with bicuspid aortic valve malformations: implications for aortic dilatation. J Thorac Catdiovasc Surg. 2003; 126:797-806. https://doi.org/10.1016/S0022-5223(03)00398-2

19. Boyum J, Fellinger E, Schmoker J, et al. Matrix metalloproteinase activity in thoracic aortic aneurisms associated with bicuspid and tricuspid aortic valves. J Thorac Cardiovasc.Surg. 2004; 127: 686-91. https://doi.org/10.1016/j.jtcvs.2003.11.049

20. Loscalzo M, Goh D, Loeys B, et al. Familial thoracic aortic dilatation and bicomissural aortic valve: a prospective analysis of natural history and inheritance. Am J Med Genet A. 2007; 143A: 1960-7. https://doi.org/10.1002/ajmg.a.31872

21. OMIM (On-line Mendelian Inheritance in Man) www.ncbi.nlm.nih.gov/omim.

22. Guizani, I., Zidi, W., Zayani, Y., Boudiche, S., Hadj-Taieb et all. Matrix metalloproteinase-3 predicts clinical cardiovascular outcomes in patients with coronary artery disease: a 5 years cohort study. 2019; Molecular Biology Reports. 46(5):4699-4707. https://doi.org/10.1007/s11033-019-04914-4

23. Liu PY, Chen JH, Li YH, et al. Synergistic effect of stromelysin-1 (matrix metallo-proteinase-3) promoter 5A/6A polymorphism with smoking on the onset of young acute myocardial infarction. Thromb Haemost. 2003; 90:132-139. https://doi. org/10.1055/s-0037-1613609

24. Niu W., Qi Y. Matrix metalloproteinase family gene polymorphisms and risk for coronary artery disease: systematic review and metaanalysis. Heart. 2012; 98(20):1483-1491. https://doi.org/10.1136/heartjnl-2012-302085

25. Xin Xu, Lihan Wang, Changfu Xu, Peng Zhang, Fendi Yong et all. Variations in matrix metalloproteinase-1, -3 , and -9 genes and the risk of acute coronary syndrome and coronary artery disease in the Chinese Han population. Coronary Artery Disease. 2013; 24(4):259-265. https://doi.org/10.1097/MCA.0b013e32835ea3af

26. Nojiri T, Morita H, Imai Y, et al. Genetic variations of matrix metalloproteinase-1 and -3 promoter regions and their associations with susceptibility to myocardial infarction in Japanese. Int J Cardiol. 2003; 92:181-186. https://oi.org/10.1016/S01675273(03)00100-1

27. Niu W., Qi Y. Matrix metalloproteinase family gene polymorphisms and risk for coronary artery disease: systematic review and metaanalysis. Heart. 2012; 98(20):1483-1491. https://doi.org/10.1136/heartjnl-2012-302085

28. Humphries S, Bauters C, Meirhaeghe A et al. The 5A6A polymorphism in the promoter of the stromelysin-1 (MMP 3 ) gene as a risk factor for restenosis. Eur. Heart J. 2002; 23(9):721-725. https://doi.org/10.1053/euhj.2001.2895

29. Hoppmann $\mathrm{P}$, Koch $\mathrm{W}$ et al. The $5 \mathrm{~A} / 6 \mathrm{~A}$ polymorphism of the stromelysin-1 gene and restenosis after percutaneous coronary interventions. Eur Heart J. 2004; 25(4):335-41. https://doi.org/10.1016/j.ehj.2003.12.004

30. Blankenberg, S., Rupprecht, H.J., Poirier, O., et al. Plasma concentrations and genetic variation of matrix metalloproteinase 9 and prognosis of patients with cardiovascular disease. Circulation. 2003; 107(12):1579-1585. https://doi.org/10.1161/01. CIR.0000058700.41738.12

31. Lacchini, R., Metzger, I.F., Luizon, M., et al., 2010. Interethnic differences in the distribution of matrix metalloproteinases genetic polymorphisms are consistent with interethnic differences in disease prevalence. DNA Cell Biol. 29(11):649-655. https://doi.org/10.1089/dna.2010.1056

32. Metzger, et al. Genetic Variants in matrix metalloproteinase-9 gene modify metalloproteinase-9 levels in black subjects. $D N A$ Cell Biol. 2012; 31(4):504-510. https://doi.org/10.1089/dna.2011.1388

33. Juan, Z., Wei-Guo, Z., Heng-Liang, S., Da-Guo, W.Association of matrix metalloproteinase 9 C-1562T polymorphism with genetic susceptibility to myocardial infarction: A meta-analysis. Current Therapeutic Research - Clinical and Experimental. 2015; 77:40-45. https://doi.org/10.1016/j.curtheres.2014.05.001

34. Wang, X., Shi, L.-Z. Association of matrix metalloproteinase-9 C1562T polymorphism and coronary artery disease: A metaanalysis. Journal of Zhejiang University: Science B. 2014; 15(3):256-263. https://doi.org/10.1631/jzus.B1300088

How to cite this article: Dana Taizhanova, Akerke Kalimbetova, Ainur Akilzhanova. Matrix metalloproteinases genes polymorphism in the development of new cardiovascular events. J Clin Med Kaz. 2020; 4(58):19-22 